\title{
SCIENTIFIC ACTIVITY OF A.S. SEREBROVSKYI (1892-1948) IN THE CONTEXT OF THE DEVELOPMENT OF FARM ANIMAL GENETICS
}

\section{Roman Bey}

\section{INTRODUCTION}

Achievements of modern molecular genetics, technology of cloning organisms, DNA technologies are largely associated with significant theoretical and practical work of domestic geneticists of the 1920's-1940's. Among intellectual elite a significant role belongs to A.S. Serebrovskyi - one of the prominent Soviet geneticists, whose creative heritage was intensely ignored in the first, and was largely not appreciated in the second half of the last century.

Some aspects of the scientist's activities were highlighted in the scientific works by M.M. Aslanian, N.B. Varshaver, N.V. Glotov', A. Bezzubtsev-Kondakov ${ }^{2}$, V. Soifer ${ }^{3}$ and other authors. But to this day, a comprehensive study of his creative activity, an analysis of scientific heritage has not yet been carried out.

The purpose of this article in the context of historical events associated with the development of domestic and world genetics during the first half of the 20th century is to present biographical data that highlights the life and fate of the famous geneticist A.S. Serebrovskyi in science; and also consider his contribution to genetics and, in general, to biological science, focusing on the scale of his ideas, its perception by contemporaries of the scientist and the significance of these ideas for our time.

The general scientific and interdisciplinary methods used to solve research tasks. Particular attention paid to special historical methods,

\footnotetext{
${ }^{1}$ Aslanian, M. M., Varshaver, N. B., \& Glotov, N. V. (1993) Aleksandr Sergeevich Serebrovskii [Aleksandr Sergeevich Serebrovskii]. Moscow, 192 s. (in Russian).

${ }^{2}$ Bezzubtcev-Kondakov, A. (2003) Evgenika kak "prokliatyi vopros» XX veka. $\mathrm{Za}$ [Eugenics as a "damned question" of the 20th century]. Russkoe delo, no. 4 (106), pp. 12-24. (in Russian).

${ }^{3}$ Soifer, V. (2004). Zagublennyi talant (Istoriia zhizni odnogo laureata) [Ruined talent (Life story of one laureate)]. Vashington, 415 s. (in Russian).
} 
source analysis. The source base of the research includes a complex of diverse documents, the basis of which are archival materials.

The article is prepared in accordance with the tasks of the state budget topic 0116U002102 "Scientific-organizational and regulatory bases of innovative activity in the system of agrarian science: theoretical and methodological, historical and scientific studies, archival, bibliographic aspects of the research".

\section{Formation of scientific outlook of A.S. Serebrovskyi. Contribution to the development of genography of species of farm animals}

A. Serebrovskyi was born on February 12, 1892 in Kursk in the family of an architect. Alexander's childhood and youth coincide with the first stage of the development of a new science - genetics. These were the years of fundamentally important discoveries in genetics, the years of its formation. At that time, the basic concepts of the mutation theory were formed, the law of the independent frequency distribution of genotypes and phenotypes in the population was established, the phenomenon of gene interaction was identified, work began on the development of the chromosome theory and was accumulated on the mechanisms of inheritance of characters. Often, theoretical thought did not keep pace with the explanation of open phenomena. By that time, Russia had developed original directions in various fields of biology, and two Russian biologists were awarded by the Nobel Prize I.I. Mechnikov and I.P. Pavlov (1904) ${ }^{4}$.

The first optional course in genetics in Russia began to be taught at the University of St. Petersburg by zoologist Y. Filipchenko (1882-1930) as early as 1913, and five years later, he organized the first department of experimental zoology and genetics in Russia. N. Vavilov (1887-1943) moved to Petrograd from Saratov, who in a short time managed to create an ensemble of first-class researchers around him. In such conditions, there was a rapid development of domestic genetics in St. Petersburg. In Moscow in 1916, on the basis of the Moscow Society of Scientific Institution, N. Koltsov (1872-1940),

\footnotetext{
${ }^{4}$ Aslanian, M. M., Varshaver, N. B., \& Glotov, N. V. (1993) Aleksandr Sergeevich Serebrovskii [Aleksandr Sergeevich Serebrovskii]. Moscow, 192 s. (in Russian).
} 
whom the famous German zoologist and geneticist R. Goldschmidt called the most educated of all biologists known to him, creates the first in Europe Institute of Experimental Biology. Four years later, $\mathrm{N}$. Koltsov invited the zoologist S. Chetverikov to organize a genetic laboratory at the institute. The famous scientists such as N. TimofeevRostovsev, B. Astaurov, S. Gershenzon, N. Dubinin, E. Balkashina, D. Romashov originates from Moscow School of Genetics. Thanks to Koltsov's school in genetics, the name of A. Serebrovskyi became widely known. In 1909, after completing his studies at the Tula Real School, entered the natural department of the Physics and Mathematics Faculty of Moscow University. He with M. Zavadovskyi, also a university student, were taking practical classes with of N. Koltsov on the invertebrate zoology course at A. Shaniavskyi People's University. After graduating from university in 1914, A. Serebrovskyi enlisted as a volunteer in the army, graduated from the school of ensigns in 1916 and for the next two years was in the army on the Caucasian front. After demobilization, he returned to Moscow to his teacher N. Koltsov and he invited him to deal with issues of private animal genetics. Soon, in 1919, he moved to the v. Slobodka, Tula Region, where an Experimental Poultry Station was organized. He researched the problem of hen genetics and his first work was devoted to the genetics of farm animals, which opened a new direction in animal husbandry. The choice of domestic chicken as an object of genetics was not accidental. A short reproductive period, high fecundity costs for conducting genetic studies allow him to achieve the significant results ${ }^{5}$.

Since 1921, A. Serebrovskyi had worked at the Anikovska Experimental Station near Zvenigorod, organized with the participation of N. Koltsov, and at the same time is listed as an assistant to the N. Koltsov Institute of Experimental Biology. At the same time, a wide range of interests of A. Serebrovskyi began to manifest himself - from issues of general biology and evolutionary teachings to specific issues of breeding individual species of agricultural animals.

High activity allowed him to conduct work in parallel in various scientific and educational institutions. From 1923-1924 A. Sereb-

${ }^{5}$ Serebrovskii, A. S. (1919) Izuchenie nasledstvennosti selskokhoziaistvennykh zhivotnykh [The study of the heredity of farm animals]. Trudovoe khoz-vo, no. 5, pp. 19-20. (in Russian). 
rovskyi successfully combines the head of the poultry department of the Moscow Zootechnical Institute (later this department was transformed into the department of genetics) and lecturing the course "Genetic analysis of farm animals" at Moscow State University. The publication in 1923 of the first edition of his book "Biological Walks", in which he expressed his deeply spiritual attitude to nature ${ }^{6}$. According to this book, which has become an example of a combination of science and poetry, many natural biologists studied.

This period of A. Serebrovskyi's life passes under events exciting the imagination of geneticists: a chromosome theory of heredity, $\mathrm{N}$. Vavilov formulates his famous law of homological series and establishes centers of origin of cultivated plants, the work of $\mathrm{S}$. Chetverikov on evolutionary genetic processes in populations is being developed. It should be noted that, despite the first wave of emigration of Russian intelligentsia to the West, the intellectual potential of geneticists of the former USSR and its contribution to the world level of development of genetics of that period was so significant that the V International Genetic Congress in Berlin (1927) noted the exceptional importance of the achievements of Soviet genetics of that period. This was the first and, unfortunately, the last triumph of domestic genetics of the 20th century.

N. Vavilov, C. Chetverikov, A. Serebrovskyi impressed by the evolutionary and genetic ideas, began to develop a new direction, which he called genogeography. The concept of "genogeography" was introduced into science by A. Serebrovsky in conjunction with the concept of "gene pool". However, the scientific fate of these new ideas turned out to be just as, and even more, perverse, as the fate of domestic genetics as a whole. After all the tragic breakdowns in the history of genetics in our country, since the 1960's, the era of its revival began. The ideas of genogeography and the gene pool still remain an undeveloped scientific heritage ${ }^{7}$.

In the late 1920's, the next stage in the development of genetics began, marked by the discovery of the possibility of artificially

\footnotetext{
${ }^{6}$ Serebrovskii, A. S. (1973) Biologicheskie progulki [Biological walks]. 3-e izd., sokr. Moscow, 68 s. (in Russian).

${ }^{7}$ Rychkov, Yu. G., Zhukova, O. V., \& Evsiukov, A. N. (2001). Genofond $i$ genogeografiia narodonaseleniia [The gene pool and population genogeography]. $\mathrm{SPb}$, vol. 1, 611 s. (in Russian).
} 
producing mutations. Biologists did not abandon the hope of artificially changing genes. N. Koltsov set his task to his students, but to no avail. However, in Leningrad in 1925, microbiologists G. Nadson and G. Filipov published a work on artificially induced mutations in yeast under the influence of radiation. Unfortunately, the conclusion of scientists about the mutagenic effect of radiation A. Serebrovskyi then rejected, saying that the yeast has no nucleus, no chromosomes, and therefore the changes obtained by G. Nadson and G. Filipov are not mutations, but, as he called them, long-term modifications. As a result, then the most important discovery of Russian scientists-genetics did not listen. But, when in 1927 G. Meller induced mutations in experiments using $\mathrm{X}$-ray radiation on Drosophila, this was perceived in world science as an outstanding discovery, for which after almost twenty years he was awarded by the Nobel Prize.

A. Serebrovskyi was shocked by G. Meller's work. In the newspaper Pravda of September 11, 1927, his article was published about this discovery under the intriguing title "The Four Pages That Excited the Scientific World". The discovery of the mutagenic properties of x-ray radiation was the starting point for a new round of development by A. Serebrovskyi of the central problem of the doctrine of heredity - the gene problem.

A. Serebrovskyi was the first in the world to disprove the fundamental conclusion about the impossibility of fragmenting the gene. He suggested that one part (the "center of the gene"), rather than the entire gene, could be mutated. Reporting at the All-Russian Congress of Zoologists, Anatomists and Histologists in Leningrad (1927), A. Serebrovskyi said that many genetics that were not clear at that time would be resolved, "if only we reject the seriously unreasonable idea of a gene as an isolated morphological parts of the chromosome that is not crushable" ${ }^{\prime 2}$. Logically developing the idea of gene divisibility, A. Serebrovskyi soon came to the conclusion that not only genes are located on the chromosome linearly, as was established by T. Morgan, but the gene itself is linear and has a certain length. In addition, he puts forward an important hypothesis in which he considers

\footnotetext{
${ }^{8}$ Serebrovskii, A. S. (1928). Problema gena i ego izmerenie [The problem of the gene and its measurement]. Tr. Vseros. sezda zoologov, anatomov $i$ gistologov, Leningrad, 14-20 dek., p. 51. (in Russian).
} 
the chromosome as a giant molecule. These revolutionary thoughts were expressed in 1926-1928, decades before it was found that the DNA molecule was shown to be the bearer of heredity and the gene was shown to be a segment of a linear DNA molecule.

Based on the assumption that the gene is extended, that it is linear, it is divisible, and when multiple alleles occur, sections of different lengths can fall out, A. Serebrovskyi in 1928 organized an experimental test of his hypothesis. The experiments to study the possibility of gene fragmentation by x-ray irradiation, begun at the Moscow Zootechnical Institute, were continued by him at the K.A. Timiryazev Biological Institute with the help of his students and staff, most of which left a noticeable mark on the history of Russian genetics. The collective work carried out under his leadership confirmed the correctness of his idea, which led to the discovery of the phenomenon of gradual allelomorphism and the creation of a theory of the complex structure of the gene (the central theory of the gene) ${ }^{9}$.

The theory of stepwise allelomorphism, suggesting the divisibility of gene, caused sharp objections from the largest geneticists, such as Stertevant, Shulyts, Goldschmidt. Highly appreciating the level of work of A. Serebrovskyi and his school, each of them offered his own interpretation of the results obtained, which, however, would leave intact the idea of the gene as an elementary unit of heredity. Subsequently, with the development of molecular biology, these postulates were fully confirmed, but the name of A. Serebrovskyi, who formulated them back in the late 1920's, is not mentioned anywhere.

From this period, extremely intense scientific and organizational activities of A. Serebrovskyi have been noted. In 1929, in addition to organizing the laboratory of genetics at the Timiryazev Biological Institute, he heads the cabinet of heredity and the constitution of a person at the Medical and Biological Institute (later the M. Gorky Medical and Genetic Institute), whose director was A. Serebrovskyi's former employee S. Levit. In 1930, after the dismissal, the arrest and expulsion from Moscow of S. Chetverikov, A. Serebrovskyi organized the department of genetics at the university and became its head. Then,

\footnotetext{
${ }^{9}$ Serebrovskii, A. S., \& Dubinin, N. P. (1929). Iskusstvennoe poluchenie mutatcii $i$ problema gena [Artificial mutation and gene problem]. Uspekhi eksperim. biologii. Ser. Biologiia, vol. 8, vyp. 4, pp. 235-247. (in Russian).
} 
without leaving other places of work, Serebrovskyi establishes the Department of Genetics and Animal Breeding at the All-Union Institute of Livestock of All-Union Academy of Agricultural Sciences named after Lenin and in the future manages it, as well as manages the laboratory in the Caucasus (in Dagestan) and the group in Middle Asia. For a number of years, he was simultaneously an employee of the Presidium of Academy and for some time served as Vice president of Academy. In addition, in the period from 1926 to 1939 A.S. Serebrovskyi was the initiator of numerous discussions on controversial issues of genetics. It was hard to say how to combine these many responsibilities, but it is well known that he was a productive scientist and a wonderful teacher, he was highly appreciated by students of the biology faculty of Moscow State University, his lectures on genetics aroused great interest and woke up the thought of young students. It was from this department that many talented genetics of the country came out. Among the personal factors of A. Serebrovskyi, which, according to the pupils, contributed to their extremely active diverse research and pedagogical activities, they called originality, ingenuity, a certain eccentricity, liveliness of mind, and the ability to be easily inspired. He was an inborn teacher, clearly and clearly bringing to the minds of listeners the position of his ideas, and at the same time a brilliant polemicist, acutely ridiculing the stupidity and ignorance of his opponents. He was a strong analyst and mathematician, and used his mathematical mindset in the development of a number of theoretical principles of genetics.

A. Serebrovskyi very early began to gravitate to philosophical and ideological discussions about science and about its new tasks in a socialist society. He attached great importance to the implementation of communist ideas in biological research and the transfer of biological ideas into communist ideology. He enthusiastically engaged in disputes over the benefits that the socialist system opens up to society and science, applied for membership in the CPSU and was accepted as a candidate for party membership. He became a staunch supporter of the correctness of Marxist-Leninist ideology in the development of human society.

From the beginning of the 1920's A. Serebrovskyi began to publish articles not only on problems of general genetics and animal genetics, but also on human inheritance. However, its introduction into 
this problem caused a significant negative resonance in different circles. Serebrovskyi's work on human heredity was initiated by N. Koltsov. At that time, N. Koltsov was the main inspirer of the development of eugenics in Russia - the science of the conscious direction and acceleration of human evolution in order to achieve the greatest perfection of man as a biological species. The ancestor of eugenics in the second half of the 20th century became F.Galton - a cousin of Ch. Darwin. A lively interest in Galton's ideas arose in a number of countries at the beginning of the 20th century. Then, thanks in large part to K. Timiryazev, they also heard about eugenics in Russia, but it reached its peak somewhat later, in the 1920's. Eugenic ideas turned out to be in tune with the daunting task of creating a man of the future, which the leaders of the new, Soviet .Russia dreamed of in the post-revolutionary years, and therefore eugenics has found especially fertile soil for itself here ${ }^{10}$. Over time, A. Serebrovskyi also joined the movement of Russian Eugenists. His vision of the practical application of eugenic ideas is most clearly presented in the article "Anthropogenetics and eugenics in a socialist society", published in 1929 and provoked harsh criticisms ${ }^{11}$.

It is easy to imagine what a wave of public condemnation these reasonings provoked. In response to the criticism that fell upon him, A. Serebrovskyi acknowledged the fallacy of some of his previous allegations. All this in a complex, taking into account the unambiguous trends of that dangerous time, as well as the significant public weight of A. Serebrovskyi as a scientist and popular teacher, could very well lead to the realization of his ideas, which would pose a significant threat to the nation. On the other hand, the creation of a society of "ideal" people, perhaps, was not at all included in the plans of totalitarian power in the USSR.

Soon, eugenics, as well as genetics, was finished in the Soviet Union. The distortion of eugenic ideas in Germany and other countries

${ }^{10}$ Serebrovskii, A. S. (1919) Izuchenie nasledstvennosti selskokhoziaistvennykh zhivotnykh [The study of the heredity of farm animals]. Trudovoe khoz-vo, no. 5, pp. 19-20. (in Russian).

${ }^{11}$ Serebrovskii, A. S. (1929) Antropogenetika $i$ evgenika v sotcialisticheskom obshchestve [Anthropogenetics and eugenics in a socialist society]. Med.-biol. zhurn., vyp. 5, pp. 3-19. (in Russian). 
has discredited this scientific direction, and now eugenics is already the past. However, the best of her legacy, the goals set before eugenics by her founders and not achieved by her, became the subject of medical genetics and is currently used by her in particular cases to control hereditary changes during the development of a child with the aim of elimination or reduction of morbidity, disability and mortality, providing the necessary quality of human life in accordance with its genotype $^{12}$.

\section{A. Serebrovskyi's contribution to the formation of the genetic basis of farm animal selection}

It is known that in the early years of A. Serebrovskyi in the house of his father, the Tula architect, there were often future leaders of the Bolshevik party, including A. Lunacharskyi and others. There is reason to believe that the pro-revolutionary the orientation of the Serebrovskyi family further facilitated his administrative growth and the scale of his ideas on transforming livestock was supported by party leaders. So, in the context of the search for new ways of introducing genetic knowledge into agricultural production, the Board of the People's Commissariat of the USSR in 1931 adopted a resolution on the wide development of the large-scale work proposed by A. Serebrovskyi and F. Liskun on remote hybridization of animals. It was planned to obtain and study hybrids of cattle with yak, zebu, banteng, guayal, bison, production of hybrids of sheep and pigs with wild species, hybrids of various species of geese, ducks. It was also planned to study the possibilities of distant hybridization (cows with buffalo, reindeer with other species of deer, etc.) and restore the fertility of barren hybrids.

Considering the facts of natural hybridization of species in nature, A. Serebrovskyi analyzed the world hybridization resources and made a successful attempt to classify them. In 1933, he published the article "Animal Hybridization as a Science", , in which he first outlined the

\footnotetext{
${ }^{12}$ Gershenzon, S. M., \& Buzhievskaia, T. N. (1996) Evgenika: 100 let spustia [Eugenics: 100 years later]. Chelovek, no. 1, pp. 16-24. (in Russian).

${ }^{13}$ Serebrovskii, A. S. (1933) Gibridizatciia zhivotnykh kak nauka [Hybridization of animals as a science]. Tr. In-ta po gibridizatcii $i$ akklimatizatcii s. $k h$. zhivotnykh $v$ Askanii-Nova, vol. 1, pp. 20-32. (in Russian).
} 
content and program of his proposed science on controlling hybridization processes, and in 1935 his monograph "Animal Hybridization" was published, containing many interesting ideas and considerations that are relevant for modernity, and until recently, remained the only one in Russian literature ${ }^{14}$. It was the solution to hybridization problems that contributed to the short-term period of A. Serebrovskyi's work in Ukraine, in the world-famous Askania-Nova Nature Reserve. Unfortunately, from this large and valuable hybridization program, much less than planned was implemented.

In 1933, A.S. Serebrovskyi was elected a corresponding member of the Academy of Sciences of the USSR, and in 1935 - Academician of the All-Union Academy of Agricultural Sciences, where he temporarily headed the department of animal husbandry. He began to argue that urgent and widespread use of genetic methods in animal breeding. His specific proposals were radical and provoked an angry confrontation between livestock breeders, as Serebrovskyi's radicalism was in sharp contradiction with the centuries-old and very thoughtful practice of breeding.

Assessing the great contribution of A.S. Serebrovskyi to the theory and practice of animal technology, one should not forget that he, like most then geneticists of the classical direction, was mistakenly convinced that there was no influence of environmental conditions on heredity. This fundamental error probably comes from the fact that geneticists-experimenters of those years, working mainly with a microscope and laboratory Drosophila lines or plant tissue cultures under fairly stable laboratory conditions, did not record any visible hereditary changes. Anthropogenic pollution of the environment was then very insignificant. And genetics, with all their vital energy and individual courage, defended their point of view. At the same time, breeders-breeders, having everyday practice of both positive and negative influence of factors of feeding and keeping the animal on the realization of his hereditary inclinations, sincerely could not understand the intransigence of geneticists. This contradiction became so acute that it further contributed to the development of tragic events for genetics in the 1930's-1950's. Unfortunately, in those years, neither the supporters

${ }^{14}$ Serebrovskii, A. S. (1935). Gibridizatciia zhivotnykh [Hybridization of animals]. M.-L., 290 s. (in Russian). 
of the chromosomal theory, nor the breeders still understood that it was not the acquired characters that were inherited, but the genetically determined rate of the body's reaction to the newly created environmental conditions. This methodological error for almost 40 years hindered the integration of the two trends in genetics into a synthetic genetic theory.

I would like to illustrate this contradiction by the example of the scientific disputes of A.S. Serebrovskyi and M.F. Ivanov, who from 1930 to 1935 were scientific consultants at the All-Union Institute of Animal Hybridization and Acclimatization of Askania-Nova. It so happened that their names became the personification of two areas in zootechnical science, the contrast of which since the midle1930's has acquired an ideological coloring.

The authority of M. Ivanov among breeders and especially livestock breeders was extremely high due to the creation of two breeds according to the technique developed by him in less than 10 years. A.S. Serebrovskyi, fascinated by the idea of introducing genetic methods into breeding, developed a new system of pedigree work in the breed, based on which he put forward the leader theory put forward by him in those years with the identification of improvement producers and the indispensable use of artificial insemination. Both M. Ivanov and A. Serebrovskyi, both with great respect for each other, but gave different emphasis to selection methods. Ivanov, as a practitionerbreeder, made extensive use of individual selection and phenotype selection at different stages of breed breeding, without detracting from the importance of evaluating animals by genotype. He believed that thus, under those specific conditions, in a short period of time, a new highly productive breed could be bred. A. Serebrovskyi criticized the phenotype assessment method in his speeches, arguing that the phenotype of a genetically valuable leader is not of fundamental importance, and also denied the importance of feeding conditions and keeping the leader to realize its genetic potential. Subsequently, he selfcritically admitted underestimation of this method.

As in many other areas, the recommendations of A.S. Serebrovskyi only came to fruition in the last decades, when conditions were created for large-scale breeding in the breed using on a large array of uterus of producers, evaluated by the quality of their breeding. Of particular note is his prediction of the need for these conditions of a 
strict genetic analysis of producers for the carriage of lethal and defective genes, translocations, etc.

Of course, after almost a century, the fundamental significance of the genetic discoveries of the 1900-1930's. It seems obvious, but we must not forget that from the time of J.B. Lamarck until the 1970's, the theory of inheritance of acquired attributes under the influence of the external environment steadily functioned. It was this theory that provided a huge range for initiative in a targeted alteration of the nature of the heredity of plants, animals, and humans in the desired direction. The chromosome theory did not create such "convenient" possibilities. Moreover, unfortunately, until the 1960s, even in genetics textbooks, a list of conditions under which open genetic laws were observed was not clearly stated. Most geneticists, these laws are simply absolutized.

Already in the early 1930's, it became apparent that biology, especially genetics, is closer to other human sciences to the humanities, the basis of which was party affiliation. It is biology that adjoins a complex of agronomic and zootechnical sciences, from which they expected the salvation of the country's national economy, destroyed during the civil war.

In 1932, the All-Union Conference on the Planning of Breeding and Genetic Research was held in Leningrad, at which A.S. Serebrovskyi was elected deputy chairman. Those were the years of active development of the Stalinist plan for the continuous collectivization of agriculture and the industrialization of heavy industry. New approaches to solving these global problems were required. Under these conditions, the fate of geneticists was made dependent on success in the practice of agricultural production. However, N. Vavilov in his report set very large, implausible volumes of tasks. These were global tasks of a strategic, but not tactical nature in the conditions of those difficult years.

The development plan of genetics, presented by A.S. Serebrovskyi, was distinguished by even more significant unreality ${ }^{15}$. During the most important works on artificial insemination of cattle, he had in mind the

${ }^{15}$ Serebrovskii, A. S. (1933) Zadachi genetiki vo vtoroi piatiletke $v$ sviazi $s$ problemami zhivotnovodstva [The tasks of genetics in the second five-year period in connection with the problems of animal husbandry]. Tr. Vsesoiuz. konf. po planirovaniiu genet.-selektc. issled., Leningrad, 25-29 iiunia 1932 g. Leningrad, pp. 46-63. (in Russian). 
replacement of natural sperm with artificial sperm. He intended to provide "a reduction in generational change by growing gonads in adult animals or in tissue cultures." Thus, in those distant 1930's, they anticipated the achievements of modern biotechnology of animal reproduction. Moreover, even such completely unrealistic problems as "obtaining mutations such as polyploidy in domestic animals were included in the five-year plan. Of course, in that period of a tough command-administrative style of managing the national economy, a total search for more and more new ones" enemies of the people, there really was such a call, but the answer was unsatisfactory.

The leaders of Russian genetics, unfortunately, did not immediately realize that, given the specifics of the attitude of the authorities towards science, which had reigned firmly in the Soviet Union since the second half of the 1930's, even the simplest lag in terms, not to mention the failure to fulfill the tasks of the practical implementation of the stated scientific obligations was absolutely unacceptable. Assessing the complexity of the relationship in the struggle between two directions in the genetics of that period Michurin-Lysenko and classical, it becomes obvious that the failure of the promises made by N.I. Vavilov and A. S. Serebrovskyi for the fiveyear period 1932-1937, significantly undermined the faith of the Soviet government in the strength and capabilities of genetics, while strengthening the position of T.D. Lysenko.

The national economy of the USSR of those years, with its many millions of illiterate population, required simple, affordable and reliable methods to increase crop yields and productivity of domestic animals. Lysenko was able to convince the Soviet people, led by the top government, in the "obvious simplicity" of obtaining these seemingly impossible results. The methods proposed by the agricultural technician were accessible to understanding both collective farm breeder practitioners and party leaders who provided ideological and economic support to T.D. Lysenko and the direction he led in biological science.

So, in the middle 1930's, Stalin relied on Lysenko and with from that moment pressure, in various forms, on biologists and, above all, on geneticists, did not stop. At first, in 1935-1936, a scientific discussion tightly controlled by the party leadership was launched. Its culmination was the IV session of the Supreme Agricultural Academy (December 19-27, 1936), the main theme of which was "The controversial issues of genetics 
and selection." The main speakers here were N. Vavilov, T. Lysenko, G. Meller, A. Serebrovsky and N. Dubinin. At this session, what was subsequently called Lysenko clearly took shape. The session was preceded by a series of arrests of scientists and administrators of science.

Since the middle 1930's, and over the next 30 years, differences in understanding the influence of environmental factors on the formation of heredity have been the scene of not only scientific disputes. Due to the specificity of the personality of T. Lysenko and a number of his associates, scientific discussions were transferred to the rails of ideological struggle, using such favorite attributes of the dictatorship of the Soviet government of that time as exposing "enemies of the people" with the active involvement.

At the beginning of 1937, after the Academy session, A.S. Serebrovskyi left the UIAH, since working conditions on the theoretical foundations of genetics and selection because of fundamental methodological differences with the leadership became impossible here. During this period, the eugenic views of A.S. Serebrovskyi expressed by him in the late 1920's began to play a negative role. The next round of bloody Stalinist repressions began, the organization of the total surveillance of many scientists. These were periods of continuous demonstrative political processes. A similar political process was outlined in biological science.

The resistance of the geneticists at the 1936 session was not broken, and the next wave of various measures to suppress science ended in the fall of 1939 with a public discussion (in the press it was called the "Conference on Genetics and Breeding") in Moscow under the auspices of the journal Under the Banner of Marxism. Now the leadership of the party and government has moved from a scientific discussion to an ideological one, thereby sharply limiting the possibilities of opponents of T. Lysenko. Lysenko himself, among other posts, was appointed to the post of director of the Institute of Genetics of the USSR Academy of Sciences, taking the place of the arrested N. Vavilov. At that time, many major professors of genetics were arrested. However, the final defeat of the classical genetics in that period still failed. The Great Patriotic War began, and then the period of restoration of the national economy.

After leaving the UIAH, A.S. Serebrovskyi concentrated all his efforts on pedagogical and scientific work at the Department of Genetics of Moscow State University, where he studied problems such as gene 
theory, the laws of the mutation process, and genetic methods of controlling harmful insects. In the same period, Serebrovsky summed up his many years of analytical studies of the most complex evolutionary problems, such as the orientation in the development of individual taxa, parallelism in the phylogenesis of similar forms, the uneven evolution of various groups and some other issues in the book "Some Problems of Organic Evolution" completed by him in 1939. However, this outstanding work was published only in 1973 and, moreover, does not contain the full volume of material written by A. Serebrovskyi ${ }^{16}$.

In 1940, A. Serebrovskyi published an article with the main principles of the method of using x-ray radiation to control harmful insects by sterilizing males due to the induction of chromosomal rearrangements ${ }^{17}$. A detailed theoretical justification of this method and determination of quantitative characteristics were carried out at the department before the start of the war, then in Ashgabat, where the university was evacuated, and after the Moscow State University returned to Moscow. A.S. Serebrovskyi was the only scientist who took with him to evacuate living material from his work. An aquarium with test tubes and flies was placed on the train instead of a suitcase with his family's belongings.

As often happens with similar works, the idea did not find a positive response in his native country and foreign geneticists took advantage of A. Serebrovsky's developments, successfully introducing them into practice. And only much later, in order to restore historical justice, his first article was translated and published in English in 1969 and two years later the fundamental work on this issue, prepared by A. Serebrovskyi himself shortly before his death out of print ${ }^{18}$.

In 1945, learning about the death of his beloved daughter Alexandra, the heiress of his ideas, just two weeks before the end of the war, she fell ill. However, he continued intensive pedagogical and scientific work at Moscow State University. Over the years,

16 Serebrovskii, A. S. (1973) Nekotorye problemy organicheskoi evoliutcii [Some problems of organic evolution]. Moscow, 168 s. (in Russian).

17 Serebrovskii, A. S. (1940). O novom vozmozhnom metode borby s vrednymi nasekomymi [About a new possible method of combating harmful insects]. Zool. zhurn. vol. 19, vyp. 4, pp. 618-630. (in Russian).

${ }^{18}$ Serebrovskii, A. S. (1971) Teoreticheskie osnovaniia translokatcionnogo metoda borby s vrednymi nasekomymi [The theoretical basis of the translocation method of controlling harmful insects]. Moscow, 87 s. (in Russian). 
A.S. Serebrovskyi completed the monograph "Selection of animals and plants", but already at the stage of layout the book was removed from print and its set was scattered. The capital work Genetic Analysis, on which A. Serebrovskyi had been working since 1925, suffered the same fate. He was very worried about this attitude to his work and the intrigue around genetics on the part of Lysenko, strokes followed one after another. In March 1947, the Department of Genetics of Moscow State University, which was constantly led by A.S. Serebrovskyi, held a genetic conference. It was, in essence, a report on the enormous work done. No one could have thought that this conference would be the last and that work in this direction would resume only decades later. Due to a serious illness, he himself was able to attend only one meeting.

A new round of Stalinist repressions of 1947-1952 contributed to the final elimination of genetics as a science. The August session of the All-Union Agricultural Academy of Agricultural Sciences of 1948 "On the Situation in Biological Science" played a significant and monstrous role in its scope and form: the session proclaimed an official ban on normal scientific genetics and selection in the country with rich scientific traditions. Agricultural science was hit, as a result, from which it was never able to recover - once after that, biological and especially genetic theory in domestic agriculture did not rise to such heights as in the 1920-1930's.

The defeat of genetics, initiated by the August session of the Higher Academy of Agricultural Sciences, mined A. Serebrovskyi: on June 26, 1948, he died. The scientist passed away at the height of his intellectual powers, one of the last representatives of the national biological school of the period of her highest flight, one of the few representatives who survived in the 1930's, survived in the 1940's and did not fall in 1950's and later, - one of those who did not give up, "did not disarm" as they used to talk about N. Koltsov, N. Vavilov, A. Serebrovsky.

In the autumn of 1940, at the 69th year of his life, N. Koltsov died of a heart attack. A 56-year-old A. Serebrovskyi died of another stroke a month before the opening of the August session of 1948. In 1951, N. Vavilov, president of the USSR Academy of Sciences, died, not having lived a few weeks before 60 , and exactly 8 years after the death of his brother, who died of starvation in a Saratov prison. 
These and many other people of that time during the last years of their lives lived not only under constant fear of physical reprisal, they lived in conditions of terrible, in their destructive power, moral repressions. Then it turned out that those who feared for their lives almost always lost their honor and dignity, who completely defended their dignity and honor - often lost their lives. And not necessarily under execution or in dungeons. Death was overtaken simply when the obsolete human organism was no longer able to withstand such inhuman emotional stress under the ever-increasing psychological pressure of the surrounding society.

\section{CONCLUSION}

Summing up the scientific work of A. Serebrovskyi, we can confidently say that in many issues of science and practice he was ahead of events by more than 50 years. So, he actively raised the question of the use of artificial insemination of farm animals in large-scale breeding conditions, revealed the prospects of using methods of culturing embryos and other techniques in animal husbandry, which only recently have been embodied in biotechnological science. For the contribution of the evolutionary ideas his work in this area, he was named among the founders of the synthetic theory of evolution, created decades after his death. A. Serebrovskyi's genogeographic ideas in the field of population genetic analysis still remain unfulfilled. His proposed translocation method of controlling harmful insects, misunderstood and rejected in the 1940's, subsequently received widespread recognition and used all over the world. A. Serebrovskyi laid the foundation for modern ideas about the structure of the gene, and his idea of duplication of genes as a factor in progressive evolution was reflected and developed in the modern science of the evolution of proteins. The phenomenon of the "burden of mutations", to which G. Meller drew attention to the end of his life and introduced this term, was almost 30 years earlier indicated by A. Serebrovskyi in the same words. His ideas about artificial insemination of people have long become the norm of medical genetics. A scientific school of A. Serebrovskyi has dozens of brilliant researchers in the field of general genetics, genetics and animal breeding. In the end, we would like to note that the scientific heritage of this outstanding scientist of the 20th century, which was largely undeservedly forgotten by the descendant, deserves a closer study and can serve as the basis for discovering new pages of genetics. 


\section{SUMMARY}

Achievements of modern molecular genetics, technology of cloning organisms, DNA technologies are largely associated with significant theoretical and practical work of domestic geneticists of the 1920-1940's. Among intellectual elite a significant role belongs to A.S. Serebrovskyi - one of the prominent Soviet geneticists, whose creative heritage was intensely ignored in the first, and was largely not appreciated in the second half of the last century.

The purpose of this article in the context of historical events associated with the development of domestic and world genetics during the first half of the 20th century is to present biographical data that highlights the life and fate of the famous geneticist A.S. Serebrovskyi in science; and also consider his contribution to genetics and, in general, to biological science, focusing on the scale of his ideas, its perception by contemporaries of the scientist and the significance of these ideas for our time.

He actively raised the question of the use of artificial insemination of farm animals in large-scale breeding conditions, revealed the prospects of using methods of culturing embryos and other techniques in animal husbandry, which only recently have been embodied in biotechnological science. He was named among the founders of the synthetic theory of evolution, created decades after his death. Serebrovsky's genogeographic ideas in the field of population genetic analysis still remain unfulfilled. His proposed translocation method of controlling harmful insects, misunderstood and rejected in the 1940's, subsequently received widespread recognition and used all over the world. A. Serebrovskyi laid the foundation for modern ideas about the structure of the gene, and his idea of duplication of genes as a factor in progressive evolution was reflected and developed in the modern science of the evolution of proteins. The general scientific and interdisciplinary methods used to solve research tasks. Particular attention paid to special historical methods, source analysis. The source base of the research includes a complex of diverse documents, the basis of which are archival materials.

\section{REFERENCES}

1. Aslanian, M. M., Varshaver, N. B., \& Glotov, N. V. (1993) Aleksandr Sergeevich Serebrovskii [Aleksandr Sergeevich Serebrovskii]. Moscow, 192 s. (in Russian). 
2. Bezzubtcev-Kondakov, A. (2003) Evgenika kak "prokliatyi vopros" XX veka. Za [Eugenics as a "damned question" of the $20^{\text {th }}$ century]. Russkoe delo, no. 4 (106), pp. 12-24. (in Russian).

3. Vavilov, Yu. N. (1997) Pismo Germana Mellera I.V. Stalinu [Letter from German Meller I.V. to Stalin]. Voprosy istorii estestvoznaniia i tekhniki, no. 1, pp. 24-32. (in Russian).

4. Vavilov, Yu. N. (1998) Avgust 1948. Predystoriia [August 1948. Background]. Chelovek, no. 3, pp. 8-38. (in Russian).

5. Gershenzon, S. M., \& Buzhievskaia, T. N. (1996) Evgenika: 100 let spustia [Eugenics: 100 years later]. Chelovek, no. 1, pp. 16-24. (in Russian).

6. Dubinin, N. P. (1973) Vechnoe dvizhenie [Perpetual motion]. Moscow, 446 s. (in Russian).

7. Rychkov, Yu. G., Zhukova, O. V., \& Evsiukov, A. N. (2001). Genofond $i$ genogeografiia narodonaseleniia [The gene pool and population genogeography]. SPb, vol. 1,611 s. (in Russian).

8. Serebrovskii, A. S. (1919) Izuchenie nasledstvennosti selskokhoziaistvennykh zhivotnykh [The study of the heredity of farm animals]. Trudovoe khoz-vo, no. 5, pp. 19-20. (in Russian).

9. Serebrovskii, A. S. (1921) O mendelirovanii mnogoplodiia $u$ cheloveka [On the manifold of multiple pregnancy in humans]. Izv. In-ta eksperim. biologii, vyp. 1, pp. 114-119. (in Russian).

10. Serebrovskii, A.S. (1926) Genetika domashnei kuritcy [Genetics of domestic chicken]. Tr. Anikov. genet. stantcii. Moscow: Novaia derevnia, vyp. 1, 137 s. (in Russian).

11. Serebrovskii, A.S. (1928). Problema gena i ego izmerenie [The problem of the gene and its measurement]. Tr. Vseros. sezda zoologov, anatomov i gistologov, Leningrad, 14-20 dek., p. 51. (in Russian).

12. Serebrovskii, A. S., \& Dubinin, N. P. (1929). Iskusstvennoe poluchenie mutatcii i problema gena [Artificial mutation and gene problem]. Uspekhi eksperim. biologii. Ser. Biologiia, vol. 8, vyp. 4, pp. 235-247. (in Russian).

13. Serebrovskii, A.S. (1929) Antropogenetika $i$ evgenika $v$ sotcialisticheskom obshchestve [Anthropogenetics and eugenics in a socialist society]. Med.-biol. zhurn., vyp. 5, pp. 3-19. (in Russian).

14. Serebrovskii, A.S. (1960) Pismo v redaktciiu [Letter to the editors]. Med.-biol. zhurn. vyp. 4/5, pp. 447-448. (in Russian).

15. Serebrovskii, A. S. (1933) Zadachi genetiki vo vtoroi piatiletke $v$ sviazi s problemami zhivotnovodstva [The tasks of genetics in the 
second five-year period in connection with the problems of animal husbandry]. Tr. Vsesoiuz. konf. po planirovaniiu genet.-selektc. issled., Leningrad, 25-29 iiunia 1932 g. Leningrad, pp. 46-63. (in Russian).

16. Serebrovskii, A. S. (1933) Gibridizatciia zhivotnykh kak nauka [Hybridization of animals as a science]. Tr. In-ta po gibridizatcii $i$ akklimatizatcii s.-kh. zhivotnykh v Askanii-Nova, vol. 1, pp. 20-32. (in Russian).

17. Serebrovskii, A. S. (1935). Gibridizatciia zhivotnykh [Hybridization of animals]. M.-L., 290 s. (in Russian).

18. Serebrovskii, A.S. (1940). O novom vozmozhnom metode borby $s$ vrednymi nasekomymi [About a new possible method of combating harmful insects]. Zool. zhurn. vol., 19, vyp. 4, pp. 618-630. (in Russian).

19. Serebrovskii, A.S. (1969). Selektciia zhivotnykh $i$ rastenii [Selection of animals and plants]. Moscow, 295 s. (in Russian).

20. Serebrovskii, A. S. (1970) Geneticheskii analiz [Genetic analysis]. Moscow, 342 s. (in Russian).

21. Serebrovskii, A.S. (1971) Teoreticheskie osnovaniia translokatcionnogo metoda borby $s$ vrednymi nasekomymi [The theoretical basis of the translocation method of controlling harmful insects]. Moscow, 87 s. (in Russian).

22. Serebrovskii, A. S. (1973) Biologicheskie progulki [Biological walks]. 3-e izd., sokr. Moscow, 68 s. (in Russian).

23. Serebrovskii, A. S. (1973) Nekotorye problemy organicheskoi evoliutcii [Some problems of organic evolution]. Moscow, $168 \mathrm{~s}$. (in Russian).

24. Soifer, V. (2004). Zagublennyi talant (Istoriia zhizni odnogo laureata) [Ruined talent (Life story of one laureate)]. Vashington, 415 s. (in Russian).

\section{Information about the author: \\ Roman Bey,}

Doctor of Historical Sciences, Senior Researcher, Chief Scientist of the Scientific Bibliography and Biography Study of the National Scientific Agricultural Library of NAAS

10, Heroiv Oborony str., Kyiv, 03127, Ukraine ORCID ID: orcid.org/0000-0003-0649-2141 